\title{
Kecerdasan emosi pemimpin sebagai tolok ukur gereja yang sehat
}

\author{
Oleh: Fredy Simanjuntak
}

Abstraksi: Hampir tidak ada gereja yang tidak mengalami konflik, gereja banyak menampung orang yang sakit, lelah secara emosi, putus asa, terluka. Terlalu sering orang-orang yang terluka diberi tahu bahwa respon emosional mereka adalah salah atau berdosa". Kegagalan gereja sering sering terjadi merupakan kesalahan dari pemimpin gereja dalam menyadari bahwa orangorang yg terluka memerlukan perasaan mereka dimengerti dan butuh tempat untuk mengeluarkan kepahitan serta keinginan untuk didengar. Gereja memerlukan pemimpin rohani baik yang berbentuk kepemimpinan tunggal maupun majemuk. Dan sudah menjadi percakapan umum di kalangan Kristen untuk menilai apakah sebuah gereja bertumbuh/sehat dengan tanda-tanda perkembangan secara kualitas dan kuantitas. Penilaian ini juga berhubungan erat dengan pemimpin rohani gereja: adakah ia memiliki IQ (kecerdasan intelektual) tinggi? Senioritas yang sudah lebih banyak makan garam pengalaman? Bagaimana dengan "orang biasa yang tidak terpelajar" seperti Petrus dan Yohanes (Kis.4:13) yang membuat pemimpin Yahudi dan tuatua/ahli Torat heran atas keberanian mereka. Banyak pemimpin gereja pada masa kini memberikan terlalu banyak penekanan atas keberhasilan menjadikan gereja sehat pada pengetahuan dan bakat saja. Jika bakat dan kognitif saja sudah cukup, mengapa anda dan saya mengenal banyak pemimpin rohani dengan kecerdasan intelektual (IQ) tinggi dan berbakat yang tidak begitu sukses untuk membangun gereja yang sehat. Dari uraian di atas penulis mencoba menganalisi sedikitnya dua hal: Pertama, Bagaimana interpretasi mengenai kecerdasan emosi secara proporsional, teologis ? Kedua, Mencari relevansi Kecerdasan Emosi Spiritual Quotient/EQ dalam kaitannya dengan pemimpin rohani gereja yang sehat? 


\section{Pendahuluan}

Selagi ada kepemimpinan di dunia, akan selalu ada pengetahuan dan intelektualitas. Selagi ada manusia di dunia, akan selalu ada banyak bakat. ${ }^{1}$ Pemimpin gereja tidak bisa menutup mata pada masalah yang dihadapi para aktivis atau pelayan terlebih kepada jemaat yang dipimpinnya. Pemimpin rohani melalui gereja bertanggungjawab memberikan pelayanan, pertolongan dan pendampingan kepada jemaat secara holistik. Artinya bukan saja secara teologis alkitabiah rohaniah semata, tetapi juga secara kejiwaan (mental) dan badaniah. Sebagaimana Yesus memberikan contoh, mengetahui orang banyak sudah mengikuti Dia dan mendengarkan khotbah-Nya (makanan rohani), la sangat peduli dengan soal perut (makanan jasmani).

Pemimpin rohani yang memiliki IQ tinggi tetapi temperamental, tidak akan serta merta mempunyai gereja yang berkualitas dengan pertambahan anggota jemaat yang signifikan. Pemimpin gereja yang mempunyai titel akademis teologi tetapi tidak dapat menguasai dirinya tidak dapat merekrut staf yang dapat mengerti jalan pikirannya yang sering berubah-ubah. Sebaliknya, pemimpin gereja yang karena satu dan lain faktor tidak berhasil menggapai kesarjanaan teologinya tetapi menggembalakan dengan sukacita, lemah lembut, panjang sabar, kasih dan penguasaan diri yang tinggi, akan mempunyai anggota gereja yang antusias, setia dan bertumbuh. Dengan kata lain pemimpin rohani seperti ini memiliki gereja yang sehat.

Keberhasilan kepemimpinan tengah berubah, termasuk para pemimpin rohani atau pemimpin gereja. Yang lalu seorang pemimpin (gereja) hanya dinilai berhasil berdasarkan tingkat inteligensia atau berdasarkan pelatihan dan pengalaman yang sudah dilaluinya. IQ menjadi tolok ukur - tetapi sejak ditemukannya $E Q$, orang-orang lebih cenderung menilai seberapa baik kita mengelola diri sendiri dan berinteraksi dengan orang lain.

Mengapa pemimpin rohani gereja sehat harus peduli dengan konsep "psikologis" Kecerdasan Emosi? Apa manfaatnya bagi gereja yang diberi tugas seperti Yesus Kristus dalam Amanat Agung; bukankah menjadikan semua bangsa murid Kristus adakah tujuan utama adanya gereja? Dalam misinya di

1John C. Maxwell, Talent is Never Enough; Tennesse USA, 2007, hlm.00 
dunia Yesus selalu berhubungan dengan orang-orang banyak, permasalahan, pergumulan dan kebutuhan mereka. Yesus selalu berada dalam kerumunan orang, orientasinya senantiasa mengarah kepada belas kasihan terhadap orang banyak, segala sesuatu yang Yesus lakukan semuanya untuk kalayak ramai bukan seperti orang Farisi dan ahli Taurat yang orientasinya selalu kepada legalisme Hukum Taurat.

Selain bagi para pemimpin rohani, Kecerdasan Emosi juga perlu dipahami jemaat sebagai anggota masyarakat agar dapat hidup berkomunitas menjadi garam dunia dan terang dunia. Kecerdasan Emosi juga bermanfaat agar memampukan semua orang percaya menghadapi problema hidup harihari bersama tetangga dan lingkungan masyarakat sehingga sedikit banyak menjadi solusi/jawaban, tempat bertanya, pemberi pertolongan, penghantar damai dan kesejukan.

Situasi yang terjadi di lingkungan gereja aliran pentakosta-karismatik pada umumnya, melatarbelakangi pemilihan judul dan rumusan masalah yang Peneliti utarakan dalam penelitian karya ilmiah ini: Adakah manfaat yang diperoleh pemimpin rohani gereja yang sehat dari Kecerdasan Emosi (EQ)? Seharusnya terjadi terobosan-terobosan dalam paradigma para pemimpin rohani terlebih dahulu, kemudian turun ke bawah kepada jemaat. Hal seperti ini tidak jauh berbeda dengan situasi yang terjadi di zaman para rasul ketika terjadi suatu perubahan dalam tata cara ibadah keagamaan misalnya, atau hal-hal di luar kebiasaan lainnya. Pada akhirnya hal-hal baru tersebut sangat berpengaruh sehingga merasuki ke semua bidang kehidupan, yang mengakibatkan semangat dan nilai-nilai "kirbat baru" harus dijalankan secara konsisten dari waktu ke waktu.

\section{Metode Penelitian}

Penelitian ini dibatasi observasi penulis, Juga dipakai metoda analisis literatur (Library Research) yaitu menganalisis buku-buku yang berhubungan dengan "Kecerdasan Emosi" dan "gereja sehat." 


\section{Gereja Yang Sehat: Apakah? Kuantitas Atau Kualitas}

Dalam pengertiannya Kata "Gereja" berasal dari kata Portugis igreya, yang jika mengingat akan cara pemakaiannya sekarang ini, adalah terjemahan dari kata Yunani kyriake. ${ }^{2}$ yang berarti yang menjadi milik Tuhan. Adapun yang dimaksud dengan "milik Tuhan" adalah: orang-orang yang percaya kepada Tuhan Yesus sebagai Juru Selamatnya. Jadi yang dimaksud dengan "Gereja adalah persekutuan para orang beriman. ${ }^{3}$

Yakob Tomatala dalam bukunya Teologi Misi menyatakan mengenai hakikat pertumbuhan gereja sebagai berikut:

pertama, Pertumbuhan ke atas, adalah pertumbuhan (kedewasaan) dalam iman dan pemahaman/penghayatan Firman (Kisah Para Rasul 2:41, 46), memiliki hubungan pengenalan akan Tuhan.

Kedua, Pertumbuhan bersama, yaitu pertumbuhan seluruh anggota jemaat secara bersama dari rohani, sosial, dan ekonomi (Kisah Para Rasul 2:4345).

Ketiga, Pertumbuhan ke luar, yaitu pertumbuhan untuk mencapai orang lain di luar anggota jemaat yang telah ada (Kisah Para Rasul 2:41-47).

Keempat, Pertumbuhan yang bertambah secara terus menerus. Pertumbuhan seperti ini adalah karya Roh Kudus dan merupakan suatu proses perkembangan yang terjadi secara bersambung yang menghasilkan pertumbuhan yang signifikan (Kisah Para Rasul 1:5; 4:4; 5:14; 9:31; 16:5; $21: 20){ }^{4}$

Ron Jenson \& Jim Stevens dalam bukunya Dinamika Pertumbuhan Gereja mendefiniskan pertumbuhan gereja sebagai berikut: kenaikan yang

${ }^{2}$ Kata kyriake sebagai sebutan bagi persekutuan para orang yang menjadi milik Tuhan, belum terdapat di dalam PB. Istilah ini baru dipakai pada zaman sesudah zaman para rasul, yaitu sebagai sebutan Gereja sebagai suatu lembaga dengan segala peraturannya. Di dalam PB kata yang dipakai untuk menyebutkan persekutuan para orang beriman adalah ekklesia, yang berarti rapat atau perkumpulan yang terdiri dari orang-orang yang dipanggil untuk berkumpul. Mereka berkumpul karena dipanggil atau dikumpulkan

${ }^{3}$ Harun Hadiwijono, Iman Kristen, Jakarta: BPK-GM, 2009, hal 362

${ }^{4}$ Tomatala Yakob, Teologia Misi (Jakarta: YT Leadership Foundation, 2003), 188-190 
seimbang dalam kuantitas, kualitas dan kompleksitas organisasi sebuah gereja lokal ${ }^{5}$.

Pertumbuhan kuantitas atau jumlah disiratkan dalam Amanat Agung Tuhan kita (Matius 28:19-20). Maksud bagian ini dicerminkan dalam jadikanlah semua bangsa murid. Kata kerja ini ditunjang oleh tindakan: pergi, baptislah dan ajarkanlah. Ayat ini dapat diterjemahkan setelah pergi, membaptiskan dan menganjurkan menjadi murid.

Pertumbuhan kualitas

Pertumbuhan kualitas merupakan perkembangan tubuh yang progresif untuk menjadi seperti kepala, Yesus Kristus. Pertumbuhan ini dicerminkan dalam "ketakutan" (ayat 43) yang melingkupi gereja dan masyarakat sementara orang-orang percaya melihat apa yang Allah sedang lakukan.

\section{Pertumbuhan organisasi}

Banyak gereja berhenti bertumbuh secara jumlah pada titik tertentu karena tidak mengembangkan kepemimpinan yang cakap dan cukup untuk melayani anggota-anggota baru. Gereja cenderung membiarkan struktur organisasi dan manajemennya membatu.

Rick Warren dalam bukunya Pertumbuhan Gereja Masa Kini mendefinisikan pertumbuhan gereja sebagai berikut:

Gereja-gereja bertambah akrab melalui persekutuan, gereja-gereja bertambah sungguh-sungguh melalui pemuridan, gereja-gereja bertambah kuat melalui ibadah, gereja-gereja bertambah besar melalui pelayanan dan gerejagereja bertambah luas melalui penginjilan. ${ }^{6}$

Rick Warren mendefinisikan gereja secara luas mulai dari perkara vertikal dan terus kepada perkara horisontal, suatu definisi yang baik yang tentunya akan membentuk sebuah gereja yang kuat, bercirikan gereja mulamula dan gereja yang memberi dampak kepada komunitasnya.

\footnotetext{
${ }^{5}$ Jenson Ron \& Stevens Jim, Dinamika Pertumbuhan Gereja (Malang: Gandum Mas, 2000), 8 .

${ }^{\circ}$ Ibid, hal 55
} 


\section{Kecerdasan Emosi}

Apakah Kecerdasan Emosi? Wikipedia mengemukakan bahwa Kecerdasan Emosi atau Emotional Quotient (EQ) adalah kemampuan, kapasitas, keterampilan atau kemampuan diri untuk mengidentifikasi, menilai, dan mengelola emosi sendiri, emosi orang lain dan emosi kelompok. ${ }^{7}$

Kecerdasan Emosi adalah karunia Tuhan bagi setiap orang, dengan kata lain semua orang memiliki EQ yang muncul dari dalam hati. Walaupun demikian, hanya sedikit orang yang mengetahui dan menyadarinya untuk memperoleh manfaatnya.

Robert K. Cooper mengatakan: ${ }^{8}$

"Kecerdasan Emosi tidak muncul dari hasil pemikiran intelektual murni tetapi dari pekerjaan hati manusia. Artinya Kecerdasan Emosi bukan tentang strategi atau trik-trik dalam melakukan atau mendapatkan sesuatu, bukan pula topeng kemunafikan untuk mengeksploitasi, menipu atau memperdaya orang lain. Sebaliknya, Kecerdasan Emosi menuntut untuk belajar mengakui, menghargai perasaan diri sendiri dan orang lain dan menanggapinya dengan tepat serta menerapkannya dalam hidup keseharian".

Sampai akhir tahun 1990an orang-orang yakin bahwa Kecerdasan Intelektual atau Intelligence Quotient (IQ) menjadi syarat utama menentukan keberhasilan baik dalam kehidupan pribadi sehari-hari maupun dalam bisnis dan dunia kerja. Akan tetapi seiring dengan perjalanan dan perkembangan ilmu pengetahuan melalui penelitian dan analisis selama bertahun-tahun, terbitlah ratusan kajian riset empiris dan laporan manajemen. Beberapa ahli menyatakan bahwa faktor utama penentu keberhasilan seseorang bukan lagi IQ semata-mata. IQ hanya menyumbangkan maksimal $20 \%$ sedangkan $80 \%$ diperoleh dari kecerdasan lain terutama EQ. ${ }^{9}$

Orang-orang yang cerdas secara intelektual boleh jadi sangat dibutuhkan untuk menciptakan persaingan (sebab pada umumnya orang-orang ini suka bersaing). Persaingan biasanya menuntut harga yang harus dibayar, antara lain: rontoknya kepercayaan, mencuatnya ketidakpastian, terjadinya celah jurang antara satu dengan yang lainnya, runtuhnya kreativitas, munculnya

\footnotetext{
${ }^{7}$ Wikipedia, Kecerdasan Emosi (http:/www.com/google)

${ }^{8}$ Robert K. Cooper \& Aywan Sawaf, Executive EO, (Jakarta: Gramedia, 2001), hal.xiv

${ }^{9}$ Daniel Goleman, Emotional Intelligence, Jakarta, Gramedia, 2000, Hal 44
} 
sinisme, membaranya amarah dan lumpuhnya loyalitas sebagai akibat dari kesombongan. ${ }^{10}$ Ini menunjukkan bahwa IQ bukan jaminan keberhasilan dalam kehidupan pribadi atau bisnis dan dunia kerja.

Peter Salovey, pencetus pertama Kecerdasan Emosi menyatakan bahwa Kecerdasan Emosi mencakup lima bagian: ${ }^{11}$

1. Mengenali emosi diri

Dasar dari Kecerdasan Emosi, yaitu kemampuan mencermati emosi diri sendiri yang sesungguhnya dengan mengetahui dan menyadari akan kekurangan dan kelebihan diri sendiri serta berusaha untuk memperbaiki kekurangan dan mengembangkan kelebihan. Hal ini akan menjadikan orang tersebut pilot atau pemandu (guide) terbaik dalam pengambilan keputusan mengenai kehidupan pribadi.

2. Mengelola emosi diri

Bagaimana menangani emosi diri sendiri sehingga dapat menyalurkan dan mengungkapkannya secara tepat dengan didasari kesadaran diri, sebab kegagalan dalam hal ini akan menyebabkan orang terperosok ke dalam masalah.

3. Memotivasi diri

Yakni kemampuan untuk meyakinkan dan menguasai diri terhadap rasa puas, mengendalikan dorongan hati sebagai landasan untuk terus berkreasi dengan mengikuti flow (aliran) melewati kesulitan mengarungi gelombang dan menggapai kesuksesan.

4. Mengenali emosi orang lain atau berempati, Yaitu keterampilan bergaul yang bergantung kepada kesadaran diri. Orang yang berempatik lebih mampu menangkap sinyal-sinyal sosial yang tersembunyi dalam diri seseorang sehingga mampu mengisyaratkan apa-apa kebutuhan orang lain.

5. Membina hubungan

Kemampuan untuk mengelola emosi orang lain, seni ini menunjang popularitas, kepemimpinan, dan keberhasilan antar pribadi.

Menurut Daniel Goleman, kesadaran diri adalah hal yang paling

\footnotetext{
${ }^{10}$ Robert K. Cooper \& Aywan Sawaf, Executive EQ, Jakarta, Gramedia, 2001, hal.xv

${ }^{11}$ Daniel Goleman, hal 44
} 
mendasar dari EQ. Kecerdasan Emosi adalah kemampuan untuk mengetahui kekurangan dan kelebihan sendiri untuk kemudian memperbaiki atau meningkatkannya; kemampuan untuk memotivasi diri sendiri; kemampuan bertahan dalam menghadapi frustasi dan tekanan; piawai dalam mengendalikan dorongan hati dan tidak melebih-lebihkan kesenangan; pandai mengatur suasana hati dan menjaga agar beban stres tidak melumpuhkan kemampuan berpikir; menjaga agar tetap produktif; selalu berempati dan senantiasa berdoa. Orang-orang yang cakap secara EQ adalah mereka yang mengetahui dan menangani perasaan sendiri dengan baik, mampu membaca dan menghadapi serta menanggapi perasaan orang lain secara efektif, dapat meraih kebahagiaan serta proaktif, memiliki keuntungan dan nilai tambah dalam semua aspek kehidupan: pribadi, pekerjaan, sosial, politik dan organisasi. ${ }^{12}$

\section{HASIL DAN PEMBAHASAN}

Sebagai hasil kajian riset empiris, Kecerdasan Emosi tidak mempunyai standar pengukuran objektif yang dapat menghasilkan nilai konkrit karena pengamatan yang dilakukan bersifat subjektif. Umumnya penelitian EQ dilakukan pada komponennya seperti: empati (paling sering diuji) yakni dengan menyuruh membaca perasaan orang lain yang direkam video ${ }^{13}$ dan hasilnya subjektif.

Menguji EQ melalui berbagai rangkaian tes dan perbandingan, bagaimana peran emosi dan EQ ketika diperhadapkan dalam berbagai kondisi dan masalah, dan bagaimana dampak EQ bagi keberhasilan hidup. Sanggupkah seseorang menahan lapar dan haus untuk waktu tertentu? (Yesaya 58:5-7). Mampukah seseorang secara spontan menghilangkan amarah dalam hitungan detik? (Amsal 15:18). Maukah seseorang meminta maaf sekalipun bukan kesalahannya?

EQ adalah perihal hati manusia. Hati murni akan menghasilkan EQ tinggi, kemampuan natural sebagai karunia Tuhan untuk kekuatan hidup setiap orang dalam mengendalikan diri menghadapi kondisi apa pun, menjadikan diri lebih berkompeten dalam pekerjaan, bahkan mampu membawa perubahan

\footnotetext{
${ }^{12}$ Daniel Goleman, hal.45-48

13 Ibid, hal.60
} 
pada diri orang lain.

Dalam hidup sehari-hari Kecerdasan Emosi (EQ) adalah sebagai tindakan yang suka mengalah, mengasihi orang lain, menunjukkan kebaikan dan belas kasihan, peduli dan pemerhati, suka menolong, memberi tumpangan (hospitality), ramah tamah, peka akan perasaan dan kebutuhan orang lain, tidak menyakiti, bijaksana dalam perkataan dan perbuatan, cekatan, sigap, tidak angkuh, suka memotivasi orang lain, mengutamakan kepentingan bersama dari pada pribadi, tidak merugikan orang lain dan suka berdoa.

Orang yang mempunyai EQ tinggi nampak lebih periang, penyabar, penyayang, lemah-lembut, komunikatif, dinamis, kontrol dirinya tinggi, tidak serakah, tidak tamak, lebih mudah mengampuni, cenderung mempunyai lebih banyak sahabat. Semua variabel ini memperlihatkan betapa besar potensi emosi apabila sudah diwujudnyatakan.

Pasiak dengan penuh jenaka membandingkan Julio Iglesias, Dorce Gamalama dan Amingwati. ${ }^{14}$ Iglesias penyanyi Spanyol dengan suaranya yang mendayu-dayu yang menaklukkan banyak hati kaum hawa awalnya adalah seorang pemain sepak bola yang kemudian patah kaki karena kecelakaan lalu banting setir meninggalkan "Real Madrid". Dorce adalah penyanyi dengan ragam lagu yang unik, bisa berdangdut, pop, keroncong, seriosa dan bisa meniru hampir semua suara yang pernah ada. la kemudian berganti kelamin luar dan pemirsa TV akan menemukan bahwa di setiap stasiun TV Dorce ada. Lain halnya dengan Amingwati, tidak ada sosok yang lebih jelek dengan tubuh kerempeng, dan wajah yang sama sekali tidak menunjukkan adanya tanda tanda seleberiti. Aming bersama-sama kawan-kawan menjadi bintang Extravaganza di sebuah stasiun TV. la lebih sering dirias amburadul menjadi wanita. Aming dan Dorce "berani malu". Kalau begitu, apa yang istimewa dari mereka bertiga? Kesungguh-sungguhan dalam bekerja "cinta pada pekerjaan" dan keikhlasan untuk mencintai pekerjaan itu. Pekerjaan berat sekali pun menjadi ringan apabila dikerjakan dengan sukacita. Hati sukacita dalam melakukan apa pun karena mencintai pekerjaan itu. Mereka juga adalah figur yang berani tampil beda.

Taufiq Pasiak, Manajemen Kecerdasan, Bandung, Mizan Pustaka IKAPI, 2006, 
Pasiak mengutarakan sepuluh prinsip "manajemen kebetulan" yang Peneliti anggap penting diperhatikan oleh para pemimpin rohani gereja yang sehat - walaupun sebenarnya semua yang berlangsung di sekitar kita tidak ada yang kebetulan (by accident) sebab semuanya sudah diatur (by design).

Pertama, bahwa setiap orang adalah orang baik sampai ia membuktikan dirinya orang jahat. Janganlah menilai baik buruknya seorang pemimpin rohani gereja sehat dari tampilan luarnya, atau kata-kata sanjungan yang indah-indah ataupun pujian yang diberikannya. Kedua, setiap orang atau peristiwa pasti memiliki dua sisi, baik dan buruk, karena itu, seorang pemimpin rohani gereja sehat harus mampu meminimalkan yang buruk dan mengoptimalkan yang baik dari diri anggota jemaat, situasi, kondisi sekitarnya dan pelbagai jenis pebgaruh luar lainnya. Jangan melihat hal-hal negatif saja dari suatu peristiwa yang seringkali berdampak pemimpin akan menjadi pemimpin yang gagal dalam kehidupan. Ketiga, jauh lebih baik mengelola perkara-perkara yang baik daripada mencerca hal-hal buruk. Seorang pemimpin rohani gereja yang sehat selayaknya pandai mengelola dengan baik termasuk membagun hubungan yang baik dan langgeng dengan orang lain. Hal mana pasti memberikan hasil yang baik. Keempat, setiap orang atau kejadian buruk pasti memberikan hikmah dan pelajaran yang berharga nilainya. Paling tidak, keburukan atau kegagalan yang dilihat atau dialami bagi seorang pemimpin gereja yang sehat telah menambah satu ilmu tentang cara-cara mengatasinya. Kelima, berbuat baik kepada orang lain akan menambah tabungan sosialnya. Sebaliknya, berbuat jahat akan mengurasnya. Jika seorang pemimpin rohani gereja sehat menista seseorang melalui kata-kata serapah atau fitnah yang disampaikannya, itu berarti ia sedang menguras tabungan kebaikan yang ada diinvestasikan pada dirinya. Sekali anda berbuat baik, anda menambah puluhan kali tabungan anda. Keenam, usaha keras dan ulet lebih mungkin mendatangkan hasil dibanding berdiam diri dan berdoa saja. Ora et Labora - berdoa sambil bekerja. Ketujuh, menyukai dan membenci seseorang jangan sampai berlebihan. Karena bukan tidak mungkin suatu waktu nanti hal itu akan menjadi terbalik. Orang yang dibenci menjadi yang dicintai, dan sebaliknya. Adanya segregasi dalam hal pilih kasih. Kedelapan, lakukanlah apa yang terbaik yang bisa seorang pemimpin rohani gereja yang sehat lakukan jika bertemu dengan 
seseorang. Do the best always. Kesembilan, lakukanlah hal-hal tertentu tanpa pamrih. Kesepuluh, peluang baik harus dibagi. Jika seorang pemimpin rohani gereja yang sehat mendapat sesuatu secara kebetulan, dan ternyata mendatangkan hasil yang baik baginya, jangan lupa menyebarkan kebaikan itu. Freely you get, freely you give.

\section{Manfaat EQ Bagi Pemimpin Gereja}

Keberhasilan dalam hidup dan pelayanan sesuai kehendak Allah bukan hanya ditentukan oleh bakat, kharisma, kecerdasan intelektual, tetapi sangat ditentukan oleh kecerdasan emosi atau kemampuan untuk menguasai diri. ${ }^{15}$ "Orang yang sabar melebihi seorang pahlawan, orang yang menguasai dirinya melebihi orang yang merebut kota" (Amsal 16:32).

Penguasaan diri menurut Alkitab khususnya dalam Perjanjian Baru, pada dasarnya adalah buah Roh. Menurut Rasul Petrus kecerdasan emosi atau penguasaan diri merupakan tangga pada perkembangan hati, yang dimulai dengan iman dan mencapai puncaknya pada kasih.

"Justru karena itu kamu harus dengan sungguh-sungguh berusaha untuk menambahkn kepada imanmu kebajikan, dan kepada kebajikan pengetahuan, dan kepada pengetahuan penguasaan diri, dan kepada penguasaan diri ketekunan, dan kepada ketekunan kesalehan, dan kepada kesalehan kasihakan saudara-saudara, dan kepada kasih akan saudara-saudara kasih akan semua orang" (2 Petrus 1:5-7).

Kepemimpinan Gereja yang Ideal

Orang yang dilayani oleh seorang pemimpin rohani harus dipandang sebagai individu seutuhnya yang terdiri dari tubuh, jiwa dan roh. Dan bahwa patut diingat oleh seorang pemimpin rohani bahwa dirinya lebih dari seorang ilmuwan, bersikap hangat tidak dingin dan mempunyai dasar pijakan pengetahuan Alkitab yang kokoh. la kompeten dalam pelayanan klinis, sensitif terhadap seluruh sasaran objektif dan subjektif yang terkait dalam pelayanannya. Untuk itu diperlukan understanding, berempati, menerima dan pendengar yang baik; diperlukan tanggapan membangun effective responding yang hangat, tidak menghakimi, dukungan moral secara profetis. Saat membicarakan masalah, pemimpin rohani bersikap proaktif dengan cara: bertanya, konfrontir, mengajar dan

${ }^{15}$ E.W.Rumpia, Kecerdasan Emosi Galatia 5:22-23, Khotbah GPI Majalengka, 12 Nopember 2008 
bersedia mendampingi dalam pergumulan-nya sampai mereka merasa merdeka sepenuhnya. ${ }^{16}$

Meskipun tidak setiap kasus yang dibawa jemaat kepada pemimpin gereja adalah tanggungjawabnya, setidaknya pemimpin menghadapi masalah jemaat mulai dari rumahtangga, pendidikan, pekerjaan, gangguan kesehatan fisik dan jiwa hingga kerasukan setan. Ini disebabkan pemimpin gereja dalam kepercayaan masyarakat desa khususnya dianggap mampu menyelesaikan persoalan hidup. Tuntutan sedemikian seharusnya cukup mendorong para pemimpin mengadakan tindakan-tindakan penyembuhan, antara lain dengan:

1. Mengidentifikasi gejala-gejala gangguan kejiwaan pada keluarga yang bersangkutan, sehingga dapat berbagi tugas dan tanggungjawab.

2. Melakukan pelayanan sesuai tanggungjawabnya dan apabila melebihi kapasitas yang ia miliki, merujuk kepada profesional bila perlu pertolongan medis/pembedahan yang harus ditangani dokter ahli di rumah sakit.

3. Menyediakan pertolongan dan tetap bertanggungjawab penuh seperti saat kunjungan, dan dukungan doa selama jemaat sakit.

4. Mendampingi mereka selama proses pemulihan untuk melewati masamasa sukar tekanan sekitarnya. ${ }^{17}$

Pada hakekatnya penyembuhan emosi-emosi yang tidak sehat ini ada dalam otoritas, kuasa dan perkenan Allah sendiri. Jika Allah berkenan maka kesembuhan pasti terjadi. Pemimpin gereja berusaha menolong dan membimbing mereka keluar dari setiap masalah dengan perbaikan Ilahi dan dengan segenap kemampuan dan profesionalismenya dalam lingkup Alkitab. Orang yang dilayaninya dalam proses kesembuhan ini diharapkan dapat bekerjasama antara lain dengan:

1. Bercerita terus terang apa adanya. Keterbukaan adalah awal dari pemulihan.

2. Tidak menyalahkan siapapun atau apapun juga. Semua ada hikmahnya.

3. Ada keinginan yang sesungguh-sungguhnya untuk sembuh.

\footnotetext{
${ }^{16}$ Yakub B. Susabda, Pastoral Konseling, (Malang: Gandum Mas, 1997), hal 23-33

${ }^{17}$ Gary R. Collins, Konseling Kristen yang Efektif, Malang, SAAT, 1996, hlm.152-155
} 
4. Mengampuni diri sendiri dan orang lain atas apa yang dialaminya.

5. Mau memulai hidup diperbaharui dan dipimpin Roh Kudus.

Gambar diri yang salah, perasaan tidak berharga dan tidak berdaya dapat sembuh dan pulih kembali dengan menerima diri apa adanya (penerimaan diri tanpa syarat), dengan sungguh-sungguh mengampuni (memberi pengampunan tanpa syarat), penghargaan diri yang benar yaitu dengan melihat diri segambar dan serupa dengan Allah (apa kata Alkitab tentang kita).

Ketidakmampuan seorang pemimpin rohani mengelola EQ merupakan kegagalan untuk memanfaatkan nilai-nilai EQ khususnya saat melakukan pelayanan. Semestinya kekuatan atau potensi emosi dimanfaatkan untuk mempermudah pelayanan. Tanpa EQ seorang pemimpin rohani cenderung menjadi pribadi yang mudah tersinggung, meledak-ledak, acuh (indifference) dan kebingungan. Kondisi ini akan menimbulkan reaksi penolakan dari yang dilayaninya. Pemimpin sendiri akan mengalami frustasi, stagnasi dan gagal dalam melakukan konseling.

Setelah melakukan pengamatan Peneliti menemukan bahwa EQ sangat memiliki hubungan erat untuk mengembangkan seorang pemimpin rohani sebagai tolok ukur sebuah gereja yang sehat. Berdasarkan uji hipotesa yaitu apabila para pemimpin gereja memiliki Kecerdasan Emosi maka konflik pribadi akibat pelayanan yang gagal, kejenuhan dan stagnasi dapat diatasi. Maka Hipotesa dapat diterima.

\section{Kesimpulan}

Kalau manusia mau jujur, sesungguhnya keberhasilan mengelola hidup (karir, rumah tangga, pergaulan) tidak hanya ditentukan oleh gelar-gelar, pendidikan tertinggi (IP), apalagi kecerdasan intelektual/IQ. Orang pintar secara akademis tidak lantas pintar mengatur hidup. Kesadaran diri (awareness), ketrampilan sosial (social skill), motivasi diri (personal motivation), dan empati yang ditemukan dalam riset-riset ilmiah merupakan kunci keberhasilan dalam mengelola hidup. Hal-hal inilah ketrampilan hidup (skill of life) yang lebih banyak dibangun oleh EQ/Kecerdasan Emosi ketimbang $\mathrm{IQ} /$ kecerdasan intelektual. 
Bagaimana seseorang mengenal dan mengerti orang lain jika ia tidak mengerti dirinya? la tidak mempunyai ketrampilan sosial. "To understand others, we must understand ourse/ves". ${ }^{18}$ EQ berkolerasi dengan kecerdasan lainnya, seperti dengan IQ, SQ/spiritual quotient, SI/social intelligence, PI/physical Intelligence dan $\mathrm{AQ} /$ adversity quotient.

Karakter dan kompetensi, atau EQ dan IQ ditambah dengan SQ hubungan dengan Tuhan adalah kompas yang tepat sebagai sarana menakhodai gereja yang sehat oleh seorang pemimpin rohani yang piawai mengelola EQ-nya dengan pelatihan dan pengembangan diri. Jauhkan asumsi yang menyamakan kepintaran/IQ dengan keberhasilan. Gelar, IP terbaik, ranking di kelas 5 atau 10 besar bukan jaminan kemampuannya mengelola kehidupan. Kita butuh lebih dari sekedar pintar. ${ }^{19}$

Mengenal dan bergaul karib dengan Allah adalah inti dari Kecerdasan Spiritual. Sebagai seorang Kristen, amat terlebih seorang pemimpin rohani yang dicitacitakan melahirkan dan mengelola gereja yang sehat maka pemikiran ini hendaknya merasuki yakni $S Q$ yang seimbang dengan $E Q$ dan IQ dan juga dengan kecerdasan lainnya sebagai penunjang ( $\mathrm{SI}, \mathrm{AQ}$ dan $\mathrm{PI}$ ). Mengenal Tuhan berarti hidup baru yaitu hidup yang diperbaharui dengan kematian "aku"nya atau manusia lama dan menjadi manusia baru. Roh Kudus memperbaharui roh manusia dan mengembalikan pada esensi awal yaitu hati nurani yang murni, sejati yang terpancar dari dalam batin yang jernih (inner life of man).

Temuan tersebut juga menjelaskan bahwa tidak satupun memuat adanya peran $I Q$, ini membuktikan bahwa $E Q$ seorang pemimpin rohani menjadi jauh lebih penting dari IQ.

Meskipun peran IQ cukup rendah, tidak berarti tidak berkorelasi dengan EQ. Menggabungkannya akan lebih baik sebab masalah kepemimpinan gereja bukan perkara yang dapat diselesaikan dengan kemampuan logika, konflik pribadi yang harus dihadapi dengan kesabaran, kepedulian, perhatian, pengertian yang tidak ada dalam rumus intelektualitas, tetapi merupakan cerminan Kecerdasan Emosi/EQ.

\footnotetext{
hlm.69-70

${ }^{18}$ Taufiq Pasiak, Manajemen Kecerdasan, Bandung, Mizan Pustaka IKAPI, 2006,

${ }^{19}$ lbid., hlm.71
} 
EQ memberi kemampuan kepada pemimpin gereja untuk membangun sikap empatik, dan menjadikannya sebagai sumber daya profesionalismenya, di tengah dunia yang piawai dalam menghadapi banyak hal yang berkaitan dengan urusan jasmaniah dan rohaniah. Ada perkara-perkara yang hanya dapat diselesaikan dengan mengelola kecerdasan emosi.

Saran

"Sebaliknya, kalau orang-orang (pemimpin rohani gereja yang sehat) dipimpin oleh Roh Allah, hasilnya ialah: Mereka saling mengasihi, mereka gembira, mereka mempunyai ketenangan hati, mereka sabar dan berbudi, mereka baik terhadap orang lain, mereka setia, mereka rendah hati, dan selalu sanggup menguasai diri". Galatia 5:22-23 (BIS)

Buah Roh dihasilkan Roh Kudus yang memimpin dan membimbing orang-orang percaya pada umumnya, dan pemimpin rohani secara khusus adalah wujud nyata hasil dari hubungan intim dengan Tuhan. Karakter Kristus ini muncul dari dalam diri dan nampak jelas dalam perilaku sehari-hari; sebagaimana layaknya buah matang dinikmati orang. Buah Roh yang tertulis dalam Galatia 5:22-23 meliputi sifat-sifat batiniah secara pribadi pemimpin rohani gereja yang sehat yaitu sifat-sifat yang berguna bukan untuk pribadinya saja, akan tetapi dapat bermanfaat bagi banyak orang dalam hubunganhubungan sosial dan prinsip-prinsip peri kelakuan. ${ }^{20}$ Pola daripada kasih adalah kasih Allah dinyatakan dalam pribadi Kristus, dengan kasih-Nya memampukan pemercaya mengasihi Allah dan orang-orang lain. Kasih tidak bertujuan mencari kepentingan diri sendiri tetapi kebaikan bagi orang-orang lain. Sukacita adalah kegembiraan yang mendalam timbul dari hubungan pribadi dengan Allah yang mencakup hal kita memenuhi kehendak-Nya. Damai sejahtera adalah kesejahteraan rohani berdasar atas pengampunan. Damai dengan Allah sangat mempengaruhi hubungan-hubungan kita dengan yang lain. Kesabaran mencakup "tahan menderita", kesabaran dan ketekunan. Allah telah bersabar kepada manusia dalam Kristus sehingga kita harus sabar satu terhadap yang lain. Kemurahan menyatakan keunggulan sifat dalam pengertian menaruh perhatian yang wajar terhadap fitrah yang lemah dari

\footnotetext{
${ }^{20}$ Tafsiran Alkitab Masa Kini, Jilid 3, Matius-Wahyu, hlm.571
} 
kepribadian manusiawi dan bagi kebutuhan manusiawi. Kebaikan tampil selaku tambahan kepada kemurahan, menyarankan pengertian umum tentang budi pekerti yang ideal, tapi dengan kebenaran yang diperlembut oleh kasih. Kesetiaan menerjemahkan kata Yunani untuk iman, kesetiaan selaku sifat dasar Kristen, istimewa dalam hubungan dengan orang-orang lain. Kelemahlembutan mengejewantahkan dua pengertian yang berhubungan, penyerahan kepada kehendak llahi dan keprihatinan terhadap orang-orang lain. Penguasaan diri menerjemahkan istilah Yunani untuk menunjukkan penguasaan/pembatasan diri. Khususnya berkaitan dengan keinginan daging, kurangnya pengekangan diri dalam setiap perangai. ${ }^{21}$

Untuk dapat memanfaatkan EQ secara maksimal dalam pelayanan pemimpin gereja Penulis menganjurkan beberapa saran, antara lain:

1. Pemimpin gereja agar tidak menganggap tabu ilmu "psikologis" mengenai EQ, "Sebab segala sesuatu adalah dari Dia, oleh Dia, untuk Dia dan kepada Dialah kemuliaan sampai selama-lamanya" (Roma 11:36).

2. Agar lebih profesional, EQ digali, dikembangkan dan diberdayakan sebesar-besarnya dalam kehidupan pribadi dan hubungan interaksi dengan bimbingan Roh Kudus.

3. Alkitab menjadi filter dari semua yang sesat dan keliru dan tipuan yang mungkin muncul dari pengetahuan sekuler yang dipelajari.

4. Masalah gereja dan problema jemaat sangatlah kompleks, pemimpin gereja tidak akan menutup diri untuk belajar dari sekolah kehidupan dan pendidikan sekuler.

5. Melayani dengan hati tidak cukup hanya dengan pikiran dan kekuatan.

${ }^{21}$ Tafsiran Alkitab Masa Kini, Jilid 3, Matius-Wahyu, hal 572 


\section{Daftar Pustaka}

Goleman Daniel (2000), Emotional Intelligence, Jakarta, Gramedia, Collins, Gary R (1996), Konseling Kristen yang Efektif, Malang, SAAT, Harun Hadiwijono, (2009) Iman Kristen, Jakarta: BPK-GM, Ron Jenson \& Stevens Jim (2000), Dinamika Pertumbuhan Gereja (Malang: Gandum Mas

Maxwell, John C (2007), Talent is Never Enough, Tennesse: Thomas Nelsonlnc Cooper, Robert K, \& Ayman Sawaf (2001), Executive EO, Jakarta: Gramedia Tomatala Yakob, Teologia Misi (2003), Jakarta: YT Leadership Foundation Wikipedia, Kecerdasan Emosi (http:/www.com/google)

Susabda, Yakub B (2002), Mengenal dan Bergaul dengan Allah, Batam: Gospel Press. 